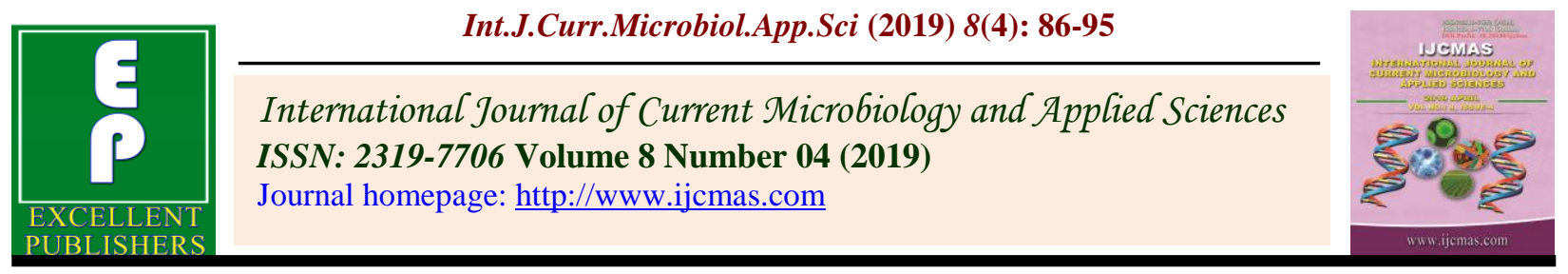

Original Research Article

https://doi.org/10.20546/ijcmas.2019.804.011

\title{
Evaluation of Bacteria Isolated from Wheat Rhizosphere for Plant Growth Promoting Attributes and Antagonistic Activity
}

\author{
Sandeep Saini ${ }^{1 *}$, Zeeshan Ahmad Faridi ${ }^{1}$, Akanksha Verma ${ }^{1}$, Ajaya T. Das, \\ Rimpa Manna ${ }^{1}$, Ankita Verma ${ }^{2}$ and C.B.S. Dangi ${ }^{1}$ \\ ${ }^{I}$ Department of Biotechnology, Faculty of Science, RKDF University, \\ Bhopal, Madhya Pradesh-462033, India \\ ${ }^{2}$ Department of Microbiology, Pragya Mahavidyalaya, Pachore, \\ Madhya Pradesh-465683, India \\ *Corresponding author
}

\section{A B S T R A C T}

\begin{tabular}{|l|}
\hline K e y w or d s \\
PGPR, Wheat, \\
Rhizopshere, \\
Antagonism
\end{tabular}

Plant growth promoting rhizobacteria are the soil bacteria present around the rhizopshere and are involved in promoting plant growth and development via different mechanisms. In order to promote sustainable agriculture, the present investigations were undertaken to screen the PGPR isolates from the plant rhizosphere. A total of eight rhizobacteria were isolated from the wheat plant rhizosphere. The biochemical tests such as Catalase test, oxidase test, nitrate reduction, Citrate Utilization, Urease test, Gelatinase test and carbohydrate utilization carried out for phenotypic identification of isolates. Based on functional characteristics, few isolates were found positive for siderophore, production, Phosphate soulubilization potential and indole production. Subsequently, these isolates also showed in vitro antagonistic activity against Macrophomina phaseolina, Sclerotinia sclerotiorum, Sclerotium rolfsii, Fusarium sp. Therefore, the present study suggested that isolated bacteria showed PGPR potential and biocontrol ability which can be used for biofertilizers as well as biocontrol agents. Consequently, these isolates can be further evaluated under in situ soil microcosm experiments.

\section{Introduction}

The rhizosphere is a dynamic environment, was first described by Hiltner (1904) as the volume of soil surrounding plant roots, which harbours diverse range of microorganisms and the bacteria colonizing this habitat are called rhizobacteria (Schroth and Hancock, 1982). Plant-associated bacteria can be classified into beneficial, deleterious and neutral groups on the basis of their effects on plant growth (Dobbelaere et al., 2003). Among the different groups, Plant growth promoting rhizobacteria (PGPR) are a group of beneficial bacteria that colonize the rhizosphere and contribute to increased growth and yield of crop plants (Kloepper and Schroth, 1978). PGPR support the growth of host plants and can stimulate plant growth, increase yield, reduce pathogen infection, as 
well as reduce biotic or abiotic plant stress, without conferring pathogenicity (Lugtenberg and Kamilova, 2009). Bacteria of diverse genera have been identified as PGPR, such as Azoarcus, Azospirillum, Azotobacter, Arthrobacter, Bacillus, Clostridium, Enterobacter, Gluconacetobacter, Pseudomonas and Serratia, however species of Pseudomonas and Bacillus are the most extensively studied (Kumar et al., 2011). PGPR can promote the plant growth by various direct and indirect mechanism such as phosphate solubilisation, nitrogen fixation, Indole-3-acetic acid (IAA) production, siderophore production and repression of soil borne pathogens by production of hydrogen cyanide and antibiotics (Glick, 1995 and Ahmed and Kibret, 2014).

Wheat represents a major renewable resource for food, feed, and industrial raw material and it is the most widely grown worldwide crop. (Reynolds et al., 2009; Montano et al., 2014) In the realm of food crops in the world, wheat occupies a prime position in the world. In India it is second most important food crop and contributes approx. $25 \%$ of total grain production of the country (Amrawat et al., 2013). In 2010, world production of wheat was 651 million tons, making it the third most produced cereal after maize (844 million tons) and rice (672 million tons) (Reynolds et al., 2009). As it is been mentioned that crops supplemented with PGPR resulted significant increase in grain yield and protein content with lower fertilizer doses as compared to conventionally applied crops (Rosas et al., 2009). Additionally, significant increase was observed in the wheat yield after supplement of rhizobacterial inoculants at locations with continuous low yields (Mader et al., 2011).

Thus, wheat (Triticum aestivum) plant has been selected as a source of rhizobacteria for the present study because among the different crops undergoing cultivation in Madhya
Pradesh, it is one of the major cash crop of this region. On account of that, the present investigation has been undertaken to isolate and characterize the rhizobacteria for plant growth promoting parameters which could be useful in preparation of bioinoculants for wheat crop.

\section{Materials and Methods}

\section{Sampling site}

The rhizospheric sample was taken from the field of Badwa village located near Karond, Bhopal. Wheat (Triticum aestivum L.) was selected as the source of rhizobacteria. Wheat Seed of variety Lok 1 were regularly used for sowing by the farmers. The geographical location of wheat field supplemented was longitude: $23^{\circ} 09^{\prime} 02.1^{\prime \prime}$, latitude: $077^{\circ} 27^{\prime} 04.3^{\prime \prime}$ and altitude: $1590 \mathrm{ft}$.

\section{Collection of soil sample}

In order to determine the indigenous bacterial population, samples were collected in a randomized manner. A quadrant of $1 \mathrm{~m}^{2}$ area $(1 \mathrm{~m} \times 1 \mathrm{~m})$ was selected at five different places of the experimental site. Samples were collected from all four corners and centre of the quadrant. This was repeated for all quadrants made in the field. Sampling was done at maturation stage of the plant. Rhizosphere soil was collected in polythene bags, closed and brought to the laboratory, and used within 6 hours for further experiment.

\section{Isolation of Rhizobacteria}

10 gm of soil of rhizospheric soil was weighed and mixed with $90 \mathrm{ml}$ sterile distilled water in $250 \mathrm{ml}$ conical flask. Flask was kept in shaker incubator for vigorous shaking for 5 to $10 \mathrm{~min}$ to form homogenous suspension. The soil solution was then than allowed to 
settle for 10-15 min before further processing. The isolation was carried out using serial dilution technique (Saini et al., 2016; Patel et al., 2015).

The bacterial colonies were recovered on Nutirent agar medium and were observed on the basis of colony colour, shape, margin, elevation and texture. Pure culture of these morphotypes was obtained by following streak plate method.

\section{Biochemical Characterization of the isolated rhizobacteria}

The potential isolates were further characterized on the basis of their staining characteristics and further investigated in terms of biochemical properties like indole, catalase, urease, citrate, ammonia, nitrate producing abilities which helped in identifying the bacteria up to genus level (Cappuccino and Sherman., 1996).

\section{Characterization of PGPR}

\section{Screening for Siderophore Production}

Siderophore production was observed on Chromeazurol ' $\mathrm{S}$ ' agar medium (Schwyn and Neilands, 1987). For this, the test organism was spot inoculated on the Chromazurol $\mathrm{S}$ (CAS) agar plates which were incubated at $28^{\circ} \mathrm{C}$. Formation of an orange halo around the bacterial colony indicated siderophore production.

\section{Phosphate solubilization}

Pikovskays's agar medium was used to demonstrate phosphate solubilization by bacteria. Bacterial isolates were spot inoculated on plates and incubated for 2-3 days at $28 \pm 2{ }^{\circ} \mathrm{C}$. Clear zone formation after incubation around bacterial colony indicated positive result (Pikovskaya, 1948).

\section{Indole production}

Bacterial culture was grown in tryptone broth followed by incubation at $28 \pm 2^{\circ} \mathrm{C}$ for $72 \mathrm{~h}$ at $120 \mathrm{rpm}$. After incubation $1 \mathrm{ml}$ of Kovac's reagent was added in tubes, shaken vigorously and allowed to stand for some time. Appearance of cherry red layer at the top indicated positive result.

\section{Extracellular enzymes production}

The bacterial isolates were evaluated for following extracelluar enzymatic activity following standard protocols.

\section{Protease production}

Bacterial isolates were streaked on skim milk agar plates to screen for protease production. The plates were incubated at $28 \pm 2{ }^{\circ} \mathrm{C}$ for $2-3$ days. Formation of clear zone around the bacterial colony indicated a positive result (Cappuccino and Sherman, 1996)

\section{Pectinase production}

Bacterial isolates were spot inoculated on $\mathrm{M}_{9}$ minimal medium supplemented with $0.5 \%$ pectin. The plates were incubated at $28 \pm 2{ }^{\circ} \mathrm{C}$ for 2-3 days. After incubation plates were overlaid with $2 \%$ CTAB. After 30 min CTAB solution was poured off, the plates were then washed with $1 \mathrm{M} \mathrm{NaCl}$. A zone around bacterial growth indicated positive result (Aneja, 2001).

\section{Cellulase production}

Pure cultures of bacteria were spot inoculated on $\mathrm{M}_{9}$ minimal salt medium supplemented with $0.5 \%$ carboxymethyl cellulose (CMC). Plates were incubated at $28 \pm 2{ }^{\circ} \mathrm{C}$ for three days. After three days the plates were overlaid with $0.1 \%$ congo red solution and washed with $1 \mathrm{M} \mathrm{NaCl}$. Cellulase positive isolates 
showed clear zone around the bacterial colonies (Amore et al., 2013).

\section{Xylanase production}

Bacterial isolates were spot inoculated on $\mathrm{M}_{9}$ Minimal medium supplemented with $0.5 \%$ larch wood xylan as carbon source. The plates were incubated at $28 \pm 2{ }^{\circ} \mathrm{C}$ for $2-3$ days. After three days the plates were flooded with congo red solution for $30 \mathrm{~min}$. Zone of clearance around the bacterial colonies was considered as positive result.

\section{Chitinase production}

Bacterial isolates were spot inoculated on $\mathrm{M}_{9}$ minimal medium supplemented with $0.5 \%$ chitin for the assay of chitinase production. The plates were incubated at $28 \pm 2{ }^{\circ} \mathrm{C}$ for $2-3$ days. After three days the plates were observed. Formation of clear Zone around the bacterial growth indicated positive result (Amore et al., 2015)

\section{Amylase production}

Bacterial cultures were spotted on starch agar medium containing $0.5 \%$ starch. Plates were incubated at $28^{\circ} \mathrm{C}$ for 3 days. The plates were over laid with freshly prepared Lugol's iodine solution. A clear zone against bluebackground confirms starch hydrolysis (Aneja, 2001).

\section{Antifungal assay}

In vitro antagonistic activity of isolated bacteria was tested against fungal pathogens Macrophomina phaseolina, Sclerotinia sclerotiorum, Sclerotium rolfsii, Fusarium sp. by employing dual plate assay (Huang and Hoes, 1976). The culture of fungal pathogens was procured from Indian Institute of Soybean Research, Indore. Fungal cultures were grown and maintained on potato dextrose agar (PDA) medium (HiMedia). The radii of the fungal colony towards and away from the bacterial colony were noted. The percentage growth inhibition was calculated using the following calculation:

$\%$ Inhibition $=[(\mathrm{R}-\mathrm{r}) / \mathrm{R} \times 100]$

Where, $r$ is the radius of the fungal colony opposite the bacterial colony and $\mathrm{R}$ is the maximum radius of the fungal colony away from the bacterial colony (Fatima et al., 2009).

\section{Results and Discussion}

\section{Isolation and morphological characteristics}

Total 8 bacterial morphotypes were obtained based on colony characteristics from the wheat rhizosphere soil samples. Based on Gram staining result total 5 isolates were found to be Gram Negative and 3 were Gram Positive. A $\mathrm{KOH}$ result also confirms the discrimination of the bacteria into Gram positive and Gram Negative group (Table 1). The isolates WRS-2, WRS-3, WRS-4 were found to be endospore positive.

\section{Biochemical characterization and} Identification

The biochemical tests such as Catalase test, oxidase test, nitrate reduction, Citrate Utilization, Urease test, Gelatinase test and carbohydrate utilization carried out for phenotypic identification of isolates (Holt et al., 1994).

All the isolates were positive for maximum biochemical activities. (Table3). Based on Biochemical results all the 8 eight isolates were positive for the catalase, Citrate and gelatinase activity. 
Table.1 Morphological characteristics of the rhizobacteria isolated from wheat rhizosphere

\begin{tabular}{|l|l|l|l|l|l|l|l|l|l|}
\hline $\begin{array}{l}\text { S. } \\
\text { No. }\end{array}$ & $\begin{array}{l}\text { Isolate } \\
\text { No. }\end{array}$ & $\begin{array}{l}\text { Gram } \\
\text { Reaction }\end{array}$ & $\begin{array}{l}\text { Endo } \\
\text { spore }\end{array}$ & $\begin{array}{l}\text { KOH } \\
\text { test }\end{array}$ & $\begin{array}{l}\text { Colour of the } \\
\text { colony }\end{array}$ & $\begin{array}{l}\text { Cell } \\
\text { Shape }\end{array}$ & Margin & Texture & Elevation \\
\hline $\mathbf{1}$ & WRS-1 & - & - & KOH+ & Offwhite & Circular & Entire & Smooth & Raised \\
\hline $\mathbf{2}$ & WRS-2 & + & + & KOH- & Creamish white & Circular & Entire & Smooth & Flat \\
\hline $\mathbf{3}$ & WRS-3 & + & + & KOH- & offwhite & Circular & Entire & Smooth & Flat \\
\hline $\mathbf{4}$ & WRS-4 & + & + & KOH- & Creamish white & Irregular & $\begin{array}{l}\text { Undulat } \\
\text { e }\end{array}$ & Rough & Raised \\
\hline $\mathbf{5}$ & WRS-5 & - & - & KOH+ & Yellow & Circular & Entire & Smooth & Flat \\
\hline $\mathbf{6}$ & WRS-6 & - & - & $\mathrm{KOH}+$ & offWhite & Circular & Entire & Smooth & Flat \\
\hline $\mathbf{7}$ & WRS-7 & - & - & $\mathrm{KOH}+$ & Creamish Brown & Circular & Entire & Smooth & Flat \\
\hline $\mathbf{8}$ & WRS-8 & - & - & $\mathrm{KOH}+$ & Red & Circular & Entire & Smooth & Raised \\
\hline
\end{tabular}

Table.2 Biochemical characteristics of the rhizobacteria isolated from wheat rhizopshere

\begin{tabular}{|l|l|c|c|c|c|c|c|}
\hline $\begin{array}{l}\text { S. } \\
\text { No. }\end{array}$ & $\begin{array}{l}\text { Isolate } \\
\text { No. }\end{array}$ & Catalase & Oxidase & $\begin{array}{l}\text { Nitrate } \\
\text { reduction }\end{array}$ & $\begin{array}{l}\text { Citrate } \\
\text { Utilization }\end{array}$ & Urease & Gelatinase \\
\hline $\mathbf{1}$ & WRS-1 & + & + & - & + & - & + \\
\hline $\mathbf{2}$ & WRS-2 & + & + & + & + & - & + \\
\hline $\mathbf{3}$ & WRS-3 & + & - & + & + & - & + \\
\hline $\mathbf{4}$ & WRS-4 & + & + & + & + & - & + \\
\hline $\mathbf{5}$ & WRS-5 & + & + & + & + & - & + \\
\hline $\mathbf{6}$ & WRS-6 & + & + & - & + & - & + \\
\hline $\mathbf{7}$ & WRS-7 & + & + & - & + & - & + \\
\hline $\mathbf{8}$ & WRS-8 & + & - & + & + & + & + \\
\hline
\end{tabular}

"- = No production; += production"

Table.3 Functional characteristics of the rhizobacteria isolated from wheat rhizosphere

\begin{tabular}{|l|l|l|l|l|l|l|l|l|l|l|}
\hline $\begin{array}{l}\text { S. } \\
\text { No. }\end{array}$ & $\begin{array}{l}\text { Isolate } \\
\text { No. }\end{array}$ & $\begin{array}{l}\text { Siderop } \\
\text { hore }\end{array}$ & $\begin{array}{l}\text { Phosphat } \\
\text { e }\end{array}$ & $\begin{array}{l}\text { Indole } \\
\text { Proteas }\end{array}$ & $\begin{array}{l}\text { Pectinase } \\
\text { e }\end{array}$ & Cellulase & Xylanase & $\begin{array}{l}\text { Chitnas } \\
\text { e }\end{array}$ & $\begin{array}{l}\text { Amylas } \\
\text { e }\end{array}$ \\
\hline $\mathbf{1}$ & WRS-1 & - & - & - & + & - & - & - & - & - \\
\hline $\mathbf{2}$ & WRS-2 & - & + & - & + & - & - & - & - & + \\
\hline $\mathbf{3}$ & WRS-3 & - & + & + & - & ++ & + & + & - & - \\
\hline $\mathbf{4}$ & WRS-4 & ++ & + & - & +++ & + & ++ & + & - & ++ \\
\hline $\mathbf{5}$ & WRS-5 & + & - & - & - & + & - & - & - & - \\
\hline $\mathbf{6}$ & WRS-6 & +++ & + & + & ++ & - & +++ & + & - & - \\
\hline $\mathbf{7}$ & WRS-7 & ++ & - & - & + & - & - & - & - & - \\
\hline 8 & WRS-8 & - & - & - & + & - & - & - & ++ & - \\
\hline
\end{tabular}

- = No production; + = Weak production; ++ = medium production; +++ = high production 
Table.4 Antagonistic activity against Macrophomina phaseolina, Sclerotinia sclerotiorum, Fusarium sp. and Macrophomina phaseolina

\begin{tabular}{|c|c|c|c|c|c|}
\hline \multirow{2}{*}{$\begin{array}{l}\text { S. } \\
\text { No. }\end{array}$} & \multirow{2}{*}{$\begin{array}{l}\text { Isolate } \\
\text { No. }\end{array}$} & \multicolumn{4}{|c|}{ \% Inhibition } \\
\hline & & $\begin{array}{l}\text { Macrophomina } \\
\text { phaseolima }\end{array}$ & $\begin{array}{l}\text { Sclerotinia } \\
\text { sclerotiorum }\end{array}$ & Fusarium Sp. & Sclerotium rolfsii \\
\hline 1 & WRS-1 & - & - & - & - \\
\hline 2 & WRS-2 & - & - & - & - \\
\hline 3 & WRS-3 & & - & - & - \\
\hline 4 & WRS-4 & $65 \%$ & $75 \%$ & $79 \%$ & $55 \%$ \\
\hline 5 & WRS-5 & - & - & - & - \\
\hline 6 & WRS-6 & $45 \%$ & $56 \%$ & $55 \%$ & $54 \%$ \\
\hline 7 & WRS-7 & $55 \%$ & $79 \%$ & $60 \%$ & $60 \%$ \\
\hline 8 & WRS-8 & _ & - & _ & _ \\
\hline
\end{tabular}

Fig.1 Functional Characterization of the isolates: A) Siderophore production B) Phosphate production, Enzymatic activities: (C) Cellulase activity (D) Protease activity (E) Amylase activity (F) Xylanase activity (G) Pectinase activity $(\mathrm{H})$ Chitinase activity. Antagonistic activity of the isolate WRS-4 against (I) Macrophomina phaseolina (J) Sclerotinia sclerotiorum (K) Fusarirum sp. (L) Sclerotiorum rolfsii
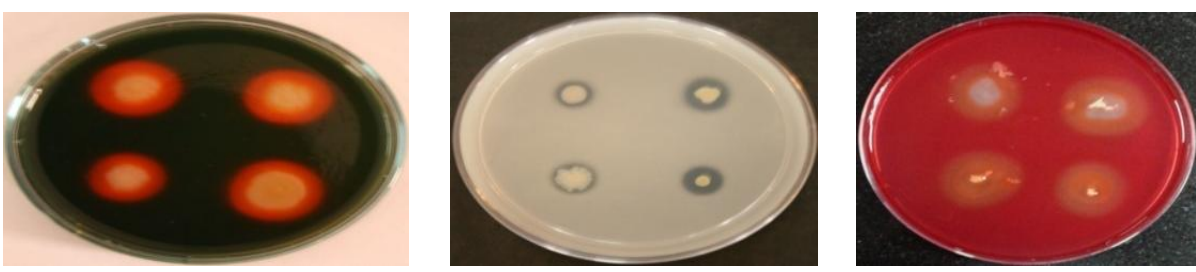

B

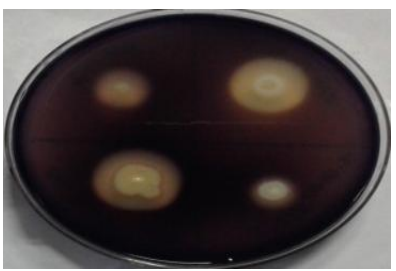

E

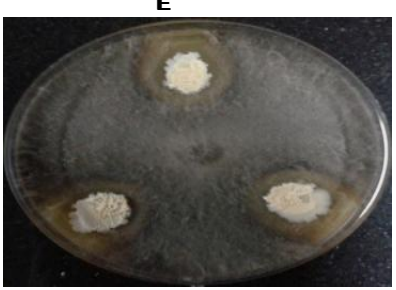

I

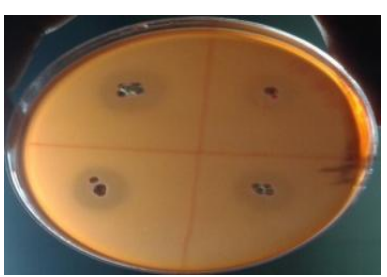

$\mathbf{F}$

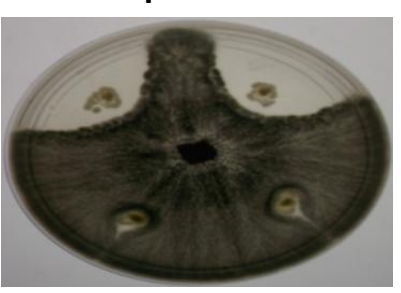

J c

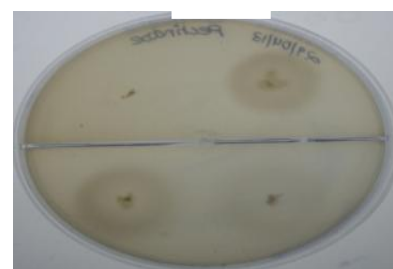

G

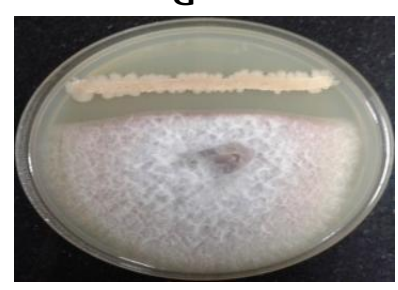

K
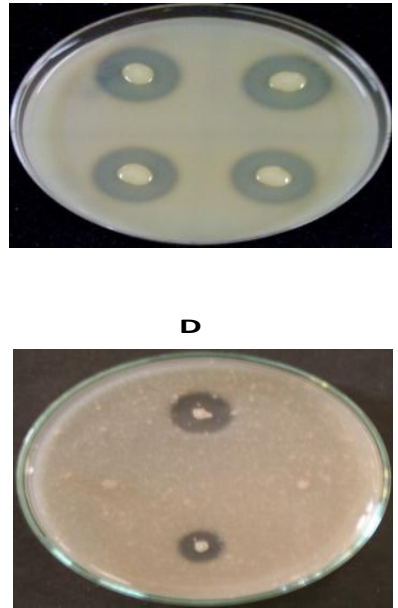

$\mathbf{H}$

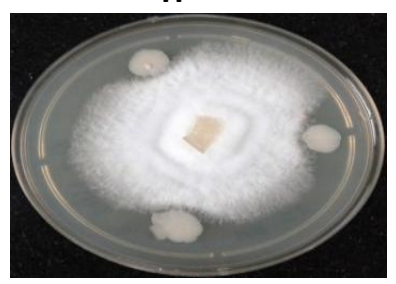

$\mathbf{L}$ 


\section{Functional characterization}

Plant growth-promoting rhizobacteria (PGPR) are known to promote plant growth by improving plant nutrition, modifying root growth architecture and plant responses to external stress factors simultaneously (Salem et al., 2007; Glick, 1995). Several bacterial genera like Bacillus, Pseudomonas, Azospirillum, Azotobacter, Bradyrhizobium, Rhizobium, have been determined as suitable candidate for plant growth promotion. In present study the morphological characterstics and biochemical activities (Table-2) reveals that the isolated bacteria have properties similar to the genus Enterobacter, Bacillus, Pseudomonas, Serratia marscecens etc. Three isolates WRS-2, WRS-3, WRS-4 were positive for endospore formation which is common characterstics of the genus Bacillus (Clauss and Berkeley, 1986). Among the eight isolates, four were siderophore, three showed Phosphate soulubilization potential and one was positive for indole production (Fig. 1). Isolate WRS-6 which is positive for siderophore production also showed positive activity for phosphate solubilization and indole production. It is well documented that rhizospheric bacteria harbors multiple plant growth promoting traits (Upadhyay and Srivastava, 2010; Kumar et al., 2012; Saini et al., 2016). There are different mechanisms by which rhizobacteria promote plant growth directly by hormone production and phosphate solubilization or indirectly by siderophore production (Lugtenberg et al., 2009). It is also well documented that rhiozbacteria isolated from wheat rhizosphere showed multiple plant growth promoting traits (Rana et al., 2011).

Results of the present work revealed that out of 8,7 isolates were positive for one or more multiple plant growth promoting traits and are thus can be used as significant PGPRs (Table 3). Bacterial extracellular enzymes production plays an important role in the management of plant pathogens as well as holds enormous economic potential (Geetha et al., 2014). Soil enzymes like cellulase, chitinase, protease, phosphatase play a critical role in maintaining soil ecology, fertility and health (Sinsabaugh et al., 1991). Due to potential industrial applications of extracellular enzymes all the 8 PGPR isolates selected were tested for their extracellular enzyme production like Cellulase, Xylanase, Pectinase, Protease, amylase, chitinase, activity. In our study all the isolates WRS-1, WRS-2, WRS-3, WRS-4, WRS-5, WRS-6, WRS-7, WRS-8 were positive for one or more extracellular enzymatic activity. (Table.3). Only one isolate WRS-8 was found to be positive for Chitinase activity. Intriguingly, isolate WRS-4, WRS-6 and WRS-8 showed invitro antagonistic activity against fungal pathogens Macrophomina phaseolina, Sclerotinia sclerotiorum, Sclerotium rolfsii, Fusarium sp (Table-4). These results were supported by Fatima et al., 2009, Walia et al., 2009, who isolated the PGPRs form wheat rhizospehre and showed in vitro antagonism against soil borne plant pathogen. Thus, it can be concluded that the isolates evaluated for multiple traits can be used as a potential candidate in plant growth promotion and biocontrol.

\section{References}

Ahemad M, Kibret M (2014) Mechanisms and applications of plant growth promoting rhizobacteria: Current perspective. Journal of King Saud University 26: 1-20.

Ahmed E, Holmstrom SJM (2014) Siderophores in environmental research: roles and applications. Microbial Biotechnology 7:196-208.

Amore A, Parameswaran B, Kumar R, Birolo L, Vinciguerra R, Marcolongo L, Ionata E, Cara FL, Pandey A, Faraco 
$\mathrm{V}$ (2015) Application of a new xylanase activity from Bacillus amyloliquefaciens XR44A in brewer's spent grain saccharification. Journal of Chemical technology and biotechnology, 90: 573-581.

Amore A, Pepe O, Ventorino V, Birolo L, Giangrande $\mathrm{C}$ and Faraco V, Industrial waste based compost as a source of novel cellulolytic strains and enzymes. FEMS Microbiol Lett 339:93-101 (2013).

Amrawat T, Solanki NS, Sharma SK, Jajoria DK and Dotaniya ML (2013) Phenology growth and yield of wheat in relation to agrometeorological indices under different sowing dates. African Journal of Agriculture Research 8(49): 6366 -6374.

Aneja K.R (2001) Experiments in Microbiology, Plant Pathology, Tissue Culture and Mushroom Production Technology. New Age International Limited, 2nd Edition.

Cappuccino JG, Sherman N. Microbiology (1996) A Laboratory Manual, The Benjamin/Cummings Publishing Co., Inc., Menlo Park, California.

Chaudhary DK, Agarwal PK and Johri BN (2009) Characterization of functional activity in composted casing amendments used in cultivation of Agaricus biosporus (Lange) Imbach'. Indian Journal of Microbiology 8:97109.

Clauss D, Berkeley RCW (1986) Genus Bacillus Cohn (1872) In bergey's manual of determinative bacteriology, Sneath, P.H.A. Baltimore, MD: Williams Wilkins, 2: 1105-1141.

Dobbelaere S, Vanderleyden J, Okon Y (2003) Plant growth-promoting effects of diazotrophs in the rhizosphere. Critical Reviews in Plant Sciences 22:107-149.

Faramarzi MA, Fazeli M, Yazdi MT, Adrangi
S, AlAhmadi KJ, Tasharrofi N, Mohseni FAc (2000) Optimization of cultural condition for production chitinase by soil isolate of Massilia timonae). Biotechnol, 2000; 8: 93-99.

Fatima Z, Saleemi M, Zia M, Sultan, T, Aslam M, Rehman RU, Fayyaz Chaudhary MF (2009). Antifungal activity of plant growth-promoting rhizobacteria isolates against Rhizoctonia solani in wheat. African Journal of Biotechnology 8:219-225.

Geetha K E. Venkatesham, A. Hindumathi and B. Bhadraiah (2014) Isolation, screening and characterization of plant growth promoting bacteria and their effect on Vigna radita (L.) R. Wilczek. International Journal of Current Microbiology and Applied Sciences 6: 799-809.

Glick BR (1995) The enhancement of plant growth promotion by free living bacteria. Candian Journal of Microbiology, 41: 109-117.

Hiltner L (1904) Ueber neuere Erfahrungen und Probleme auf dem Gebiete der Bodenbakteriologie und unter besonderer BerUcksichtigung der Grundungung und Brache. Arb Deut Landw Gesell. 98:59-78.

Holt J, Krieg N, Sneath P, Staley J, Williams $S$ (1994) Bergey's manual of determinative bacteriology. Williamson and Wilkins.

Huang HC, and Hoes JAC (1976) Penetration and infection of Sclerotinia sclerotiorum by Coniothyrium minitans. Can J of Bot 54, 406-410.

Jonathan D.G. Jones, Karen L.Grady1, Trevor V. Suslow and John R. Bedbrook (1986) Isolation and characterization of genes encoding two chitinase enzymes from Serratia marcescens The EMBO Journal 5: 467-473.

Kloepper JW, Schroth MN (1978) Plant growth promoting rhizobacteria on 
radishes, In: Proceedings of the 4 international conference on plant pathogenic bacteria, Angers, France, pp 8798-882.

Kumar A, Prakash A, Johri BN (2011) Bacillus as PGPR in Crop Ecosystem. Maheshwari DK (eds) Bacteria in Agrobiology: Crop Ecosystems. Springer-Verlag Berlin Heidelberg, New York pp 37-59.

Kumar A, Saini S, Wray V, Nimtz M, Prakash, A, Johri BN (2012) Characterization of an antifungal compound produced by Bacillus sp. strain A5F that inhibits Sclerotinia sclerotiorum. Journal of Basic Microbiology 52: 670-678.

Lugtenberg B, Kamilova F (2009) Plant Growth Promoting Rhizobacteria. Annual Review of Microbiology 63:541-556.

Lugtenberg B, Kamilova F (2009) PlantGrowth-Promoting Rhizobacteria. Annual Review Microbiology 63: 541-556.

Mader P, Kaiser F, Adholeya A, Singh R, Uppal HS, Anil K, et al., (2011) Inoculation of root microorganisms for sustainable wheat-rice and wheatblack gram rotations in India. Soil Biology Biochemistry 43:609-19.

Patel PV and Desai PB (2015) Isolation of Rhizobacteria from paddy field and their traits for plant growth promotion research. Journal of Recent Sciences 4: $34-41$.

Perez-Montano F, Alias-Villegas C, Bellogín RA, Del Cerro P, Espuny MR, Jimenez-Guerrero I, Baena-Lopez FJ, Ollero FJ, Cubo T (2014) Plant growth promotion in cereal and leguminous agricultural important plants: From microorganism capacities to crop production Microbiological Research 169: $325-336$

Pikovskaya RI (1948). Mobilization of phosphorus in soil in connection with the vital activity of some microbial species. Microbiologia. 17:362-370.

Rana A, Saharan B, Joshi M, Prasanna R, Kumar K, Nain L (2011) Identification of multi-trait PGPR isolates and evaluating their potential as inoculants for wheat. Annals of Microbiology 61: 893-900.

Reynolds M, Foulkes MJ, Gustavo A, Slafer GA, Berry P, Parry MAJ et al., (2009) Raising yield potential in wheat Journal of experimental botany 60: 1899-918.

Rosas SB, Avanzin G, Carlier E, Pasluosta C, Pastor N, Rovera M. Root colonization and growth promotion of wheat and maize by Pseudomonas aurantiaca SR1 (2009) Soil Biology and Biochemistry 41:1802-6.

Saha M, Sarkar S, Sarkar B, Sharma BP, Bhattacharjee S, Tribedi P (2015) Microbial siderophores and their potential applications: a review. Environment Science and Pollution Research DOI 10.1007/s11356-0154294-0.

Saleem M, Arshad M, Hussain S, Bhatti AS (2007) Perspectives of plant growth promoting rhizobacteria (PGPR) containing ACC deaminase in stress agriculture. Journal of Industrial Microbiology Biotechnology. 34:635648.

Saini S, Verma A, Kumar A, Prakash A, Sharma SK, Ramesh A and Johri BN (2016) Identification and Characterization of antifungal metabolite producing Pseudomonas protegens strain BNJ-SS-45 isolated from rhizosphere of wheat crop (Triticum aestivum L.) 2 (6): 69-76.

Schroth M N and Hancock JG (1982) Disease-suppressive soil and rootcolonizing bacteria. Science 216:1376-81. 
Schwyn B, Neiland JB (1987) Universal chemical assay for the detection and determination of siderophores. Analytical Biochemistry 160:47-56.

Sinsabaugh, R.L., Antibus, R.K. and Linkins, A.E. (1991). An enzymic approach to the analysis of microbial activity during plant litter decomposition. Agric Ecosyst Environ 34, 43-54.

Upadhyay A and Srivastava S (2010) Evaluation of multiple plant growth promoting traits of an isolate of Pseudomonas fluorescens strain Psd.
Indian Journal of Experimental Biology 48: 601-609.

Zuo Y and Zhang F (2011) Soil and crop management strategies to prevent iron deficiency in crops. Plant and Soil 339: 83-95.

Walia A, Mehta P, Chauhan A and Shirkot CA (2013) Antagonistic activity of plant growth promoting Rhizobacteria isolated from tomato Rhizosphere against soil borne fungal plant pathogens 6(4): 571-580.

\section{How to cite this article:}

Sandeep Saini, Zeeshan Ahmad Faridi, Akanksha Verma, Ajaya T. Das, Rimpa Manna, Ankita Verma and Dangi, C.B.S. 2019. Evaluation of Bacteria Isolated from Wheat Rhizosphere for Plant Growth Promoting Attributes and Antagonistic Activity. Int.J.Curr.Microbiol.App.Sci. 8(04): 86-95. doi: https://doi.org/10.20546/ijcmas.2019.804.011 